\title{
PENDIDIKAN TAHFIZ ANAK USIA DINI (TAUD)
}

\author{
Oleh : Ahmad Rifa'i, M.Pd.I*
}

\begin{abstract}
Abstrak
Pada awal perkembangan anak adalah masa yang sangat penting, jika anak pada masanya sudah ditanami agama serta mencintai al-Quran sejak dini maka besarnya akan menjadi anak yang berpikir cerdas, daya hafal yang kuat dan dapat mengamalkan kandungan al-Quran. Dengan itu akan terbentuk insan yang berakhlakul karimah. Pendidikan agama bagi seorang anak merupakan hal yang penting karena bekal bagi kehidupan mereka nantinya. Al-Quran merupakan kitab umat islam dimana anak harus bisa membaca dan mempelajarinya.

Di antara pelajaran yang terkait dengan mempelajari Al Qur'an adalah Pendidikan Tahfiz Anak Usia Dini. Tahfizh Al Qur'an merupakan pelajaran termudah bagi anak-anak. Sebab program Tahfizhul Qur'an teknik belajarnya sederhana. Cukup dengan mendengar dan mengucapkan secara berulang, baik itu mendengar bacaan kita sendiri ataupun mendengar bacaan orang lain. Yang terpenting bacaan yang didengar tersebut adalah bacaan yang benar, supaya hafalan Al Qur'annya juga benar. Semakin intensif anak-anak mendengar bacaan Al Qur'an setiap harinya, secara konsisten dan kontinu, maka hafalan Al Qur'annya akan semakin mudah dan semakin cepat. Sehingga tidak mustahil anak-anak bisa hafal Al Qur'an 30 juz sebelum mereka beranjak dewasa
\end{abstract}

Kata Kunci : Pendidikan,Tahfiz anak, Usia dini

\section{A. Pendahuluan}

Mendengar kata hafal al-Quran, bukanlah hal yang asing lagi diera modern saat ini, telah banyak pondok pesantren yang menyelenggarakan pendidikan tahfizh, bahkan sekolah biasa juga menjadikan tahfizh sebagai pendidikan tambahan (extrakurikuler/muatan local), belum lagi menjamurnya event tahfizh di tingkat nasional bahkan tingkat international, dimana pesertanya tidak hanya orang dewasa bahkan anak-anak yang belum mengerti tentang al-Quran sekalipun mampu mengikuti event musabaqah tahfizh 
Quran tingkat nasional hingga international, tercatat Musa ${ }^{1}$ hafizh cilik Indonesia sempat menghebohkan media indonesia dengan keberhasilannya meraih juara 3 Musabaqah Hifzil Quran (MHQ) Internasional' di Sharm El-Sheikh Mesir 2016, melihat kemampuan Musa yang sangat muda tersebut mampu menghafal al-Quran mengingatkan pada sebuah peribahasa belajar diwaktu keceil seperti melukis diatas batu belajar diwaktu besar seperti melukis diatas air. ${ }^{2}$ Makna yang melekat dalam perkataan itu adalah: "Ingatan saat kita muda begitu kuat. Kalau kita belajar, maka apa yang kita pelajari itu akan melekat kuat dalam kepala kita, seperti orang yang melukis di atas batu. Sedangkan mereka yang belajar di waktu tuanya, ingatannya tidak begitu kuat. Mereka ibarat orang yang melukis di atas air, selesai dilukis, hilanglah sudah." Bahkan jika membuka lembaran sejarah ulama terdahulu, beberapa ulama besar yang memiliki ilmu multidimensi, ternyata sudah hafal-Quran sejak usia yang sangat belia. Ada yang berusia 8 tahun sudah hafal-Quran, ada juga yang 10 tahun. Ketika imam asy-Syafi'i dibawa ibunya ke tanah Hijaz, yakni kota Makkah, ada juga yang menyebutkan tempat dekat Makkah, mulailah imam Syafi'i menghafal al-Quran sehingga ia berhasil merampungkan

* Penulis adalah dosen Sekolah Tinggi Ilmu AlQuran (STIQ) Amuntai Kalimantan Selatan. Menyelesaikan S2 di SPs UIN Maulana Malik Iberahim Malang.

${ }^{1}$ La Ode Musa, biasa disapa Abang Musa. Adalah putra dari pasangan Laode Abu Hanifa (34) dan Yulianti (29).Lahir di Bangka Barat pada 26 Juli 2008, musa adalah anak pertama dari empat bersaudara.Adiknya Lukman (5) Hindun (3) dan Zainal (1).Seperti layaknya anak kecil, musa pun mengalami kesulitan saat pertama bejalar al Qur'an.Usia dua tahun Musa sudah membaca Alquran. Ketika umurnya hampir enam tahun dia sudah hafiz Quran. - See more at: http://bimasislam.kemenag.go.id/post/berita/profil-musa-bocah-indonesia-yang-jadijuara-ajang-hafidz-tingkat-dunia-\#sthash.ht4K9hOJ.dpuf

${ }^{2}$ Pernyataan ini bisa kita dapati dalam kitab Jami' Bayanil 'Ilmi wa Fadhlihi, karya Ibnu Abdil Barr, jilid 1 halaman 357. Beliau berkata, "Dari Ma'baddari AlHasan Al-Bashri, dia berkata:

Jurnal Ilmiah Al QALAM, Vol. 11, No. 23, Januari-Juni 2017 
hafalannya pada usia tujuh tahun dan juga hafal kitab al-muwatta' (karya imam malik) dalam usia 10 tahun. Pada usia 15 tahun (ada yang mengatakan 18 tahun), imam Syafi'i berfatwa setelah mendapat izin dari syaikhnya yang bernama Muslim bin Khalid az-zanji. ${ }^{3}$ Ternyata setelah diperhatikan yang menjadi keistemewaan seorang bisa menjadi hafizh al-Quran bukan pada kemampuan yang dimiliki akan tetapi pada kemauan yang kuat dan usaha yang maskimal yang dilakukan, sehingga hal ini mendasari setiap orang tua yang ingin menjadikan anaknya sebagai hafizh al-Quran, karena Musa sang hafizh cilik bisa menghafal al-Quran secara sempurna dari usia dua tahun sang ayah terus mendidiknya dengan al-Quran, begitupula dengan Imam Syafie yang tidak lepas dari peran sang ibu dalam yang menjadikannya sebagai imam besar yang karyanya terus dikenang sampai saat ini.

\section{B. Pemanfaatan Golden Years anak}

Pada masa usia dini anak mengalami masa keemasan (the golden years) yang merupakan masa dimana anak mulai peka dan sensitif untuk menerima berbagai ransangan. Masa peka pada masingmasing anak berbeda, seiring dengan laju pertumbuhan dan perkembangan anak secara individual. Masa peka adalah masa terjadinya kematangan fungsi fisik dan psikis yang siap merespon stimulasi yang diberikan oleh lingkungan. Masa ini juga merupakan masa peletak dasar untuk mengembangkan kemampuan kognitif, motorik, bahasa sosio emosional, agama dan moral.

Pendidikan anak usia dini (PAUD) merupakan fondasi bagi perkembangan kualitas sumber daya manusia selanjutnya. Karena itu

${ }^{3}$ Syaikh M. Hasan al-jamal, Biografi 10 Imam Besar, (Jakarta: Pustaka alKautsar, 2005), hal. 79.

Jurnal Ilmiah Al QALAM, Vol. 11, No. 23, Januari-Juni 2017 
peningkatan penyelenggaraan PAUD sangat memegang peranan yang penting untuk kemajuan pendidikan di masa mendatang. Arti penting mendidik anak sejak usia dini dilandasai dengan kesadaran bahwa masa kanak-kanak adalah masa keemasan (the Golden Age), karena dalam rentang usia dari 0 sampai 5 tahun, perkembangan fisik, motorik dan berbahasa atau linguistik seorang anak akan tumbuh dengan pesat. Selain itu anak pada usia 2 sampai 6 tahun tahun yang dilakukan melalui pemberian rangsangan pendiikan untuk membantu pertumbuhan dan perkembangan jasmani serta rohani agar anak memiliki kesiapan untuk memasuki pendidikan lebih lanjut ${ }^{4}$ dan beragam, sehingga di kemudian hari anak bisa berdiri kokoh dan menjadi sosok manusia yang berkualitas.

Ada dua tujuan diselenggarakannya pedidikan anak usia dini yaitu sebagai berikut :

1. Membentuk anak yang berkualitas, yaitu anak yang tumbuh dan berkembang sesuai dengan tingkat perkembangannya, sehingga memiliki kesiapan yang optimal didalam memasuki pendidikan dasar serta mengarungi kehidupan di masa dewasa.

2. Membantu menyiapkan anak mencapai kesiapan belajar( akademik ) di sekolah.

Menurut Dr. Damanhuri Rosadi, pengembangan manusia yang utuh dimulai sejak anak dalam kandungan dan memasuki masa keemasan atau Golden Age pada usia 0-6tahun. Masa keemasan ini sangat penting bagi perkembangan intelektual, emosi, dan sosial anak

${ }^{4}$ Mansyur, Pendidikan Anak Usia Dini dalam Islam (Yogyakarta: Pustaka Pelajar. 2005) hal. 75.

Jurnal Ilmiah Al QALAM, Vol. 11, No. 23, Januari-Juni 2017 
dimasa datang dengan memperhatikan dan menghargai keunikan setiap anak.

Dalam pandangan Islam anak merupakan amanah di tangan kedua orang tuanya. Hatinya yang bersih merupakan permata yang berharga, lugu dan bebas dari segala macam ukiran dan gambaran. Ukiran berupa didikan yang baik akan tumbuh subur pada diri anak, sehingga ia akan berkembang dengan baik dan sesuai ajaran Islam, dan pada akhirnya akan meraih kebahagiaan di dunia dan di akhirat. Jika anak sejak dini dibisakan dan dididik dengan hal-hal yang baik dan diajarkan kebaikan kepadanya, ia akan tumbuh dan berkembang dengan baik dan akan memperoleh kebahagiaan serta terhindar dari kesengaraan/siksa baik dalam hidupnya di dunia maupun di akhirat kelak. Hal ini senada dengan firman Allah dalam Q.S. at-Tahrîm / 66:6 sebagai berikut :

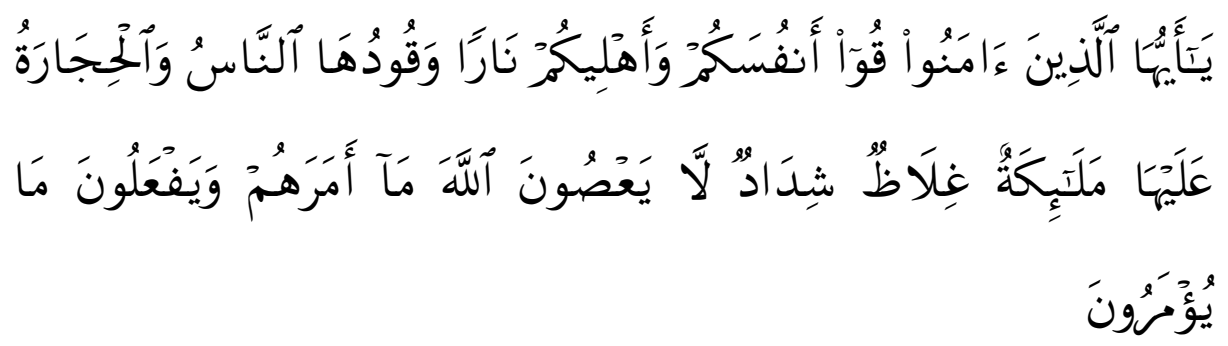

Artinya: "Hai orang-orang yang beriman, peliharalah dirimu dan keluargamu dari api neraka yang bahan bakarnya adalah manusia dan batu; penjaganya malaikat-malaikat yang kasar, yang keras, yang tidak mendurhakai Allah terhadap apa yang diperintahkan-Nya kepada mereka dan selalu mengerjakan apa yang diperintahkan. ${ }^{5}$ 
Dalam mendukung perkembangan anak pada usia-usia selanjutnya, termasuk pada usia dini, yang menjadi kewajiban orang tua adalah memberikan didikan positif terhadap anak-anaknya, sehingga anak-anaknya tersebut tidak menjadi/mengikut ajaran Yahudi, Nasrani atau Majusi, melainkan menjadi muslim yang sejati. Mendidik anak dalam pandangan Islam, merupakan pekerjaan mulia yang harus dilaksanakan oleh setiap orang tua, hal ini sejalan dengan sabda Rasul:

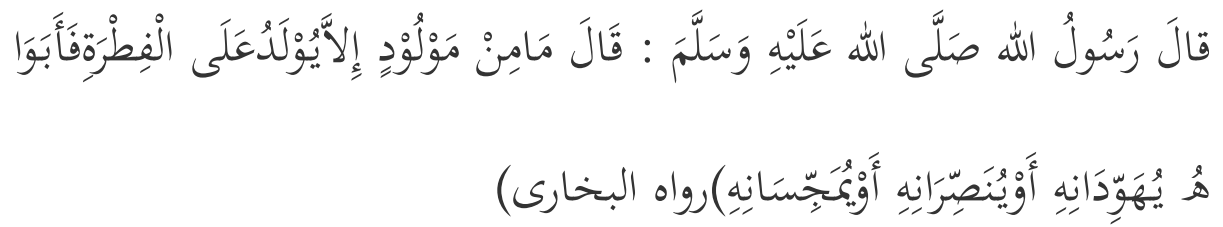

Artinya : "Setiap anak dilahirkan atas fitrah (kesucian agama yang sesuai dengan naluri), sehingga lancar lidahnya, maka kedua orang tuanyalah yang menjadikan dia beragama Yahudi, Nasrani, atau Majusi." (H.R. Bukhori)

Risalah Hadist Nabi telah menjustifikasi akan pentingnya menyelenggarakan pendidikan kepada anak usia dini, juntifikasi itu memberikan arti bahwa penyelenggaraan pendidikan pendidikan kepada anak usia dini adalah merupakan perintah yang didalamnya memiliki makna ibadah yang Agung. Inilah kesempurnaan sebuah ajaran, dimana Islam mengajarkan tentang pentingnya proses pembentukan generasi muslim dari sejak sedini mungkin untuk membangun pribadi-pribadi muslim yang kaffah (sempurna).

Oleh karena itu sudah sepantasnya bagi orang tua untuk memperhatikan masalah pendidikan anaknya dengan sebaiknyabaiknya. ${ }^{6}$

${ }^{6}$ http://intanchiechielita.blogspot.co.id/2016/01/makalah-pendidikan-anakusia-dini-dalam.html 7 Maret 2017

Jurnal Ilmiah Al QALAM, Vol. 11, No. 23, Januari-Juni 2017 
Segala sesuatu adalah berproses, demikian juga dalam hal mendidik anak. Berikut beberapa tahapan dalam membina dan mendidik anak

\section{Melatih Otak Anak Usia Dini Melalui Berpikir}

1. Berpikir pada masa bayi

Ketertarikan dalam berpikir selama masa bayi terfokus secara khusus pada informasi konsep dan kategorisasi. Konsep adalah kategori yang menggelompokan objek, peristiwa dan karakteristik berdasarkan ciri-ciri umum. Bayi membentuk konsepkonsep pada masa -masa awal perkembangan mereka. Bayi ber usia 3 bulan mulai membentuk kategori berdasarkan informasi visual. Bayi yang berusia 6 bulan juga menunjukan ke mampuan mengkategorikan bentuk-bentuk geometri, suara laki-laki dan perempuan, serta kursi dan meja.

Jean mandler $(2003,2004)$ berpendapat bahwa kategori awal ini di deskripsikan sebagai kategorisasi septual,yakni kategorisasi yang di dasarkan pada gambaran perseptual yang serupa pada suatu opjek, seperti ukuran warna ,gerakan dan juga bagian -bagian spesifik dari suatu objek,contoh nya kaki atau tangan.

Pada usia 7 atau 9 bulan, bayi membentuk kategori konseptual berdasarkan perbedaan ciri visual.

2. Berpikir pada masa kanak -kanak 
Pemikiran pada masa anak-anak, lebih terpengaruh oleh kejadian yang terjadi secara kebetulan daripada suatu pola yang menyeluruh. Seringkali, anak-anak mempertahankan teori-teori mereka tanpa mempertimbangkan bukti-bukti yang ada. Anak-anak akan melalui 'olah raga mental' dalam usahanya mempersatukan informasi-informasi baru yang kontradiktif dengan kepercayaankepercayaan yang ada dalam diri mereka. Contohnya, setelah mempelajari tata surya, anak-anak seringkali menyimpulkan bahwa ada dua tipe bumi: yang pertama adalah dunia datar dimana mereka tinggal, dan yang lain adalah bumi bulat seperti deskipsi guru mereka.

\section{Berfikir untuk Menghafal Al-Quran}

Di antara keistimewaan al-Quran adalah Allah mudahkan ia dengan semudah-mudahnya. Allah SWT berfirman dalam Q.S. alQamar / 54 : 17 sebagai berikut :

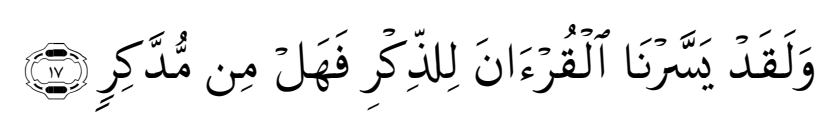

Artinya : "Dan sesungguhnya telah Kami mudahkan al-Quran untuk peringatan, maka adakah orang yang mengambil pelajaran?” (QS. Al-Qamar: 17).

Ayat tersebut terulang empat kali dalam surah yang sama, hal ini menunjukkan bahwa Allah benar-benar memberikan kemudahan alQuran untuk dihafal dan dipelajari, dan pada akhir ayat Allah memberikan pertanyaan adakah orang yang mau mengambil pelajaran.

Jurnal Ilmiah Al QALAM, Vol. 11, No. 23, Januari-Juni 2017 
Al-Quran juga mudah untuk dihafalkan. Ini adalah sebuah realita yang dirasakan banyak orang dan mereka lihat di kehidupan nyata. Kita bisa melihat di masyarakat, banyak orang-orang yang menghafalkan al-Quran 30 juz, padahal masih anak kecil. Kita juga menyaksikan, ada orang yang hafal al-Quran padahal usianya telah lanjut. Dan juga menyaksikan, para penghafal al-Quran, padahal mereka tidak mengerti bahasa Arab. Mereka tidak paham artinya tapi mereka bisa menghafalnya. Ini semua adalah bentuk kemudahan alQuran untuk dihafalkan. Dan ini adalah kemudahan dari Allah SWT.

Kata menghafal juga berasal dari kata حفظا - يحفظ - حفظ yang berarti menjaga, memelihara dan melindungi. ${ }^{7}$ Dalam kamus Bahasa Indonesia kata menghafal berasal dari kata hafal yang artinya telah masuk dalam ingatan tentang pelajaran atau dapat mengucapkan di luar kepala tanpa melihat buku atau catatan lain. Kemudian mendapat awalan me-menjadi menghafal yang artinya adalah berusaha meresapkan ke dalam pikiran agar selalu ingat. ${ }^{8}$ Kata menghafal dapat disebut juga sebagai memori. Dimana apabila mempelajarinya maka membawa seseorang pada psikologi kognitif, terutama bagi manusia sebagai pengolah informasi. Secara singkat memori melewati tiga proses yaitu perekaman, penyimpanan dan pemanggilan. ${ }^{9}$

Metode hafalan (makhfudzat) adalah suatu teknik yang digunakan oleh seorang pendidik dengan menyerukan peserta didiknya

\footnotetext{
${ }^{7}$ Mahmud Yunus, Kamus Arab-Indonesia,( Jakarta: PT. Mahmud Yunus Wadzuhryah, 1990), cet.II, hal. 105

${ }^{8}$ Desy anwar, Kamus Lengkap Bahasa Indonesia, (Surabaya: Amelia, 2003) cet. 1 , hal. 318 .

${ }^{9}$ Jalaluddin Rakhmat, Psikologi Komunikasi, Edisi Revisi, (Jakarta: Remaja Rosda Karya, 2005) Cet. 22, hal. 63.
}

Jurnal Ilmiah Al QALAM, Vol. 11, No. 23, Januari-Juni 2017 
untuk menghafalkan sejumlah kata-kata (mufradat) atau kalimatkalimat maupun kaidah-kaidah. ${ }^{10}$

Metode menghafal mempunyai beberapa kelebihan. Kelebihan dari metode menghafal adalah:

1. Menumbuhkan minat baca siswa dan lebih giat dalam belajar.

2. Pengetahuan yang diperoleh siswa tidak akan mudah hilang karena sudah dihafalnya.

3. Siswa berkesempatan untuk memupuk perkembangan dan keberanian, bertanggung jawab serta mandiri. ${ }^{11}$

4. Membangkitkan rasa percaya diri.

5. Belajar dengan cara menghafal adalah sederhana dan mudah.

6. Sebagai solusi ketika terjadi kecemasan atau perasaan tidak mampu menguasai dalam memahami materi pelajaran, dapat mencoba dikuasai dengan menghafalkannya. ${ }^{12}$

\section{E. Kiat Menghafal}

1. Mulai membaca dan menghafal yang paling mudah, yaitu surat Al-Fatihah. Kemudian lanjutkan dengan juz 30 (juz 'amma). Mengawali dengan yang mudah akan membantu untuk langkah selanjutnya.

2. Tentukan kadar hafalan dalam sehari, dengan kadar yang mudah dipenuhi, hingga akhirnya hafalannya kuat. Itu juga akan memudahkan proses menghafal selanjutnya. Kadar ini berbeda

\footnotetext{
${ }^{10}$ Abdul Mujib, Ilmu Pendidikan Islam, (Jakarta: Kencana, 2006) hlm. 209.

${ }^{11}$ Armei Arif, Pengantar Ilmu Metodologi Pendidikan Islam, (Jakarta: Ciputat Press, 2001), hal. 166.

${ }^{12}$ Nana Syaodih Sukmadinata, Landasan Psikologi Proses Pendidikan, (Bandung: Remaja Rosda Karya, 2003) cet. 1, hlm. 190
}

Jurnal Ilmiah Al QALAM, Vol. 11, No. 23, Januari-Juni 2017 
tiap orang, tergantung kecerdasan dan kecepatan hafal yang dimiliki.

3. Persering muraja'ah (mengulang-ulang) sampai benar-benar hafal. Jangan sampai ada hari yang terlewati tanpa hafalan baru maupun mengulang hafalan sebelumnya.

4. Motivasi dengan hadiah bila telah selesai menghafal satu juz dengan sempurna, dan hadiah tidak mesti mahal, bisa dengan makan-makanan yang lebih lezat dari sebelumnya.

5. Awali dengan talqin (membacakan) dan tardid (memperdengarkan berulang kali). Biasanya ini adalah awal modal dalam menghafal, kemudian ajari anak cara membaca (Al-Quran), sampai nanti dia mahir membaca Al-Quran sendiri tanpa perlu didampingi saudarinya atau gurunya.

6. Jika anak sudah mencapai usia wajib-shalat dan berakal, ajarkan dia agar mengulangi hafalannya dengan cara membaca (surat yang telah dihafalnya) dalam shalat, baik shalat fardhu maupun nafilah (sunnah).

7. Ulangi hafalannya dengan mendengar Handphone atau Laptop, agar terpadu antara baiknya pelafalan dan baiknya cara baca. Kesempatan ini juga bermanfaat untuk mengulang hafalan dan memperkuatnya.

8. Pilih waktu yang sesuai untuk menghafal - selagi tidak sibuk dan banyak urusan - misalnya pilih waktu setelah fajar (subuh) atau waktu antara maghrib dan isya. Jauhi masa ketika lapar, capek, atau mengantuk.

9. Puji sang anakdi hadapan tetangga atau kerabat, untuk menyemangati dan memotivasi para tentangga dan kerabat 
supaya ikut menghafal Al-Quran. Baca dua surat al-mu'aqqidzat (yaitu Al-Falaq dan An-Nas), agar terhindar dari 'ain orang yang dengki.

10. Sangat penting bagi sang anak untuk memakai satu mushaf, jangan gonta-ganti, karena dengan itu dia akan lebih kuat mengingat letak ayat.

11. Motivasi sang anak untuk menuliskan ayat yang telah dihafalnya, hingga tergabung antara pelajaran menulis dan kuatnya hafalan. ${ }^{13}$

\section{F. Kesimpulan}

Tahfiz anak usia dini (TAUD) merupakan fondasi bagi perkembangan kualitas sumber daya manusia selanjutnya. Karena itu peningkatan penyelenggaraan TAUD sangat memegang peranan yang penting untuk kemajuan pendidikan di masa mendatang.

Ada dua tujuan diselenggarakannya pedidikan anak usia dini yaitu sebagai berikut : Membentuk anak yang berkualitas, yaitu anak yang tumbuh dan berkembang sesuai dengan tingkat perkembangannya, sehingga memiliki kesiapan yang optimal didalam memasuki pendidikan dasar serta mengarungi kehidupan di masa dewasa. Membantu menyiapkan anak mencapai kesiapan belajar( akademik ) di sekolah. Dalam mendukung perkembangan anak pada usia-usia selanjutnya, termasuk pada usia dini, yang menjadi kewajiban orang tua adalah memberikan didikan positif terhadap anak-anaknya, sehingga anak-anaknya tersebut tidak menjadi/mengikut ajaran Yahudi, Nasrani atau Majusi, melainkan menjadi muslim yang sejati.

\footnotetext{
${ }^{13} \mathrm{https} / / /$ muslimah.or.id/5727-kiat-membimbing-anak-usia-5-tahun-dalammenghafal-al-Quran.html 7 Maret 2016
}

Jurnal Ilmiah Al QALAM, Vol. 11, No. 23, Januari-Juni 2017 
Risalah Hadist Nabi telah menjustifikasi akan pentingnya menyelenggarakan pendidikan kepada anak usia dini, juntifikasi itu memberikan arti bahwa penyelenggaraan pendidikan pendidikan kepada anak usia dini adalah merupakan perintah yang didalamnya memiliki makna ibadah yang Agung. Inilah kesempurnaan sebuah ajaran, dimana Islam mengajarkan tentang pentingnya proses pembentukan generasi muslim dari sejak sedini mungkin untuk membangun pribadi-pribadi muslim yang kaffah (sempurna).

Metode hafalan (makhfudzat) adalah suatu teknik yang digunakan oleh seorang pendidik dengan menyerukan peserta didiknya untuk menghafalkan sejumlah kata-kata (mufradat) atau kalimatkalimat maupun kaidah-kaidah mengahafalkan al-Quran diusia dini. Mulai membaca dan menghafal yang paling mudah, yaitu surat AlFatihah.

Tentukan kadar hafalan dalam sehari, dengan kadar yang mudah dipenuhi. Persering muraja'ah (mengulang-ulang), Motivasi dengan hadiah,Awali dengan talqin (membacakan) dan tardid (memperdengarkan berulang kali). Ulangi hafalannya dengan mendengar Handphone atau Laptop. 


\section{DAFTAR PUSTAKA}

Abdil Barr, Ibnu . Jami' Bayanil 'Ilmi wa Fadhlihi. jilid 1

Al-jamal , Syaikh M. Hasan. Biografi 10 imam besar, jakarta: pustaka al-kautsar tahun.

Anwar, Desy. Kamus Lengkap Bahasa Indonesia, Surabaya: Amelia, 2003, cetakan. 1

Arif, Armei. Pengantar Ilmu Metodologi Pendidikan Islam, Jakarta: Ciputat Press, 2001)

Mansyur. Pendidikan Anak Usia Dini dalam Islam. Yogyakarta: Pustaka Pelajar. 2005

Mujib , Abdul. Ilmu Pendidikan Islam. Jakarta: Kencana, 2006

Rakhmat , Jalaluddin. Psikologi Komunikasi, Edisi Revisi, Jakarta: Remaja Rosda Karya. 2005. Cet. 22

Syaodih Sukmadinata, Nana. Landasan Psikologi Proses Pendidikan. Bandung: Remaja Rosda Karya, 2003, cet. 1

Yunus, Mahmud. Kamus Arab-Indonesia. Jakarta: PT. Mahmud Yunus Wadzuhryah, 1990. cet.II

\section{Internet}

http://bimasislam.kemenag.go.id/post/berita/profil-musa-bocahindonesia-yang-jadi-juara-ajang-hafidz-tingkat-dunia\#sthash.ht4K9hOJ.dpuf

http://intanchiechielita.blogspot.co.id/2016/01/makalah-pendidikananak-usia-dini-dalam.html 7 Maret 2017

https://muslimah.or.id/5727-kiat-membimbing-anak-usia-5-tahundalam-menghafal-al-Quran.html 7 Maret 2016 